\title{
EFEKTIFITAS BENTUK HURUF MEDIUM LEAFLET DALAM MENINGKATKAN PENGETAHUAN PETANI JAGUNG DI KELURAHAN RAHANDOUNA KECAMATAN POASIA KOTA KENDARI
}

\author{
Sitti Nur Isnian $^{\left.1^{*}\right)}$, Tjandra Buana $^{1}$, Risya Septiani Rezky Putri ${ }^{1)}$ \\ ${ }^{1} J u r u s a n$ Penyuluhan Pertanian Fakultas Pertanian Universitas Halu Oleo Kendari 93232 \\ ${ }^{*}$ Corresponding author : sitti.isnian@gmail.com \\ To cite this article: \\ Isnian, S., Buana, T., \& Putri, R. (2020). Efektifitas Bentuk Huruf Medium Leaflet dalam Meningkatkan \\ Pengetahuan Petani Jagung di Kelurahan Rahandouna Kecamatan Poasia Kota Kendari. Jurnal Ilmiah \\ Membangun Desa dan Pertanian, 5(5), 160 - 166. doi:http://dx.doi.org/10.37149/jimdp.v5i5.12548
}

Received: June 23, 2020; Accepted: October 06, 2020; Published: October 12, 2020

\begin{abstract}
This study departs from the phenomenon of the presence of downy mildew disease in corn farming by corn farmers in Rahandouna Village, Poasia Sub-District, Kendari City, Southeast Sulawesi. Control efforts have been made in the last 3 years through increasing farmers' knowledge by utilizing the medium leaflet, but the downy mildew is still a problem that results in the production of corn which is not optimal. In-depth research is needed to ensure the effectiveness of the leaflet medium used to increase farmers' knowledge. Therefore this study aims to reveal the effectiveness of the leaflet medium in increasing farmers' knowledge and to strive to improve its effectiveness by focusing on the design of the letters. The research was conducted in Rahandouna Sub-District, Poasia District, Kendari City, which was conducted for 1 month, January 2020, with 36 respondents. The research was designed as an experimental study with pre-post-test treatment. The results of the study which were calculated through the effective formula using the t-test showed that the leaflet medium was effective in increasing farmers' knowledge with an effective value of $65.29 \%$, with the design of an upright letter shape. It is hoped that the leaflets produced from this research can effectively increase farmers' knowledge so that the downy mildew disease can be controlled.
\end{abstract}

Keywords: counseling media; effectiveness; knowledge enhancement; leaflets

\section{PENDAHULUAN}

Pengetahuan adalah faktor pertama dalam membentuk kempetensi petani. Kompetensi petani adalah perwujudan perilaku untuk merencanakan serangkaian aktifitas dalam mencapai target. Kompetensi merujuk pada kemampuan petani secara umum untuk menjalankan usahatani atau menjalankan tugas-tugas dan fungsi-fungsi pekerjannya (Manyamsari \& Mujibburrahmad, 2014). Kompoten merupakan keterampilan fungsional yang dibutuhkan untuk menjalankan tugas pada suatu pekerjaan sesuai standar yang ditetapkan. Kompoten diartikan sebagai memiliki pengetahuan dan keterampilan yang memadai untuk melaksanakan pekerjaan (Palan, 2008).

Upaya menciptakan kompetensi petani, peran penyuluhan menjadi suatu hal yang niscaya. Penyuluhan adalah suatu proses perubahan perilaku petani yang meliputi pengetahuan, sikap, dan keterampilan sehingga petani mampu menolong dirinya sendiri dalam memecahkan masalah pertaniannya (Mardikanto, 2010). Penyuluhan adalah proses sistematis untuk: meningkatkan pengetahuan terhadap suatu masalah (Ban \& Hawkins, 1999). Penyuluhan adalah proses pembelajaran bagi pelaku utama serta pelaku usaha agar mereka mau dan mampu menolong dan mengorganisasikan dirinya dalam mengakses informasi pasar, teknologi, permodalan, dan sumber daya lainnya, sebagai upaya untuk meningkatkan produktivitas, efisiensi usaha, pendapatan, dan kesejahteraannya, serta meningkatkan kesadaran dalam pelestarian fungsi lingkungan hidup (Kementan, 2018).Pada akhirnya penyuluhan bermuara pada tujuan meningkatkan kesejahteraan petani (Nazariah, 2012) dan (Ruyadi et al., 2017).

Penyuluhan, sebagai suatu proses pembelajaran, pendidikan non formal bagi petani, dalam memberikan informasi guna meningkatan pengetahuan petani, menggunakan leafleat sebagai media 
penyuluhan. Leafleat sebagai sebagai sebuah medium penyuluhan, fokus utamanya pada peningkatan pengetahuan. Bentuk medium leaflet yang sederhana, mudah dibawa kemana-mana, serta informasi yang tersajipun jelas sehingga mudah dibaca dimanapun membuat medium leaflet mampu meningkatkan pengetahuan dan perilaku lebih tinggi daripada media poster (Gani et al., 2014).

Medium leaflet merupakan bentuk penyampaian informasi atau pesan-pesan melalui lembaran yang dilipat dengan ukuran standar 8.5 × 11 inchi yang berisi informasi dalam bentuk kalimat maupun gambar atau kombinasi mengenai suatu hal atau peristiwa tertentu untuk diketahui oleh masyarakat (Bovee \& Arens, 1986). Leaflet adalah sebuah media penyampai pesan yang dideffinisikan sebagai selebaran yang ditata dalam lembaran kertas yang dilipat menjadi dua (4 halaman) serta berisikan pesan tulisan lebih banyak daripada gambar, tidak berjilid tidak berkulit dengan ukuran 8,5 × 11 inchi sebagai salah satu media informasi memiliki kelebihan kemampuannya menguasai waktu, sehingga dapat dibaca kapan saja, berulang-ulang dan dapat disimpan, dengan halaman tercetak pada satu sisi atau kedua sisinya. Leaflet adalah bahan cetak tertulis berupa lembaran yang dilipat tapi tidak dimatikan/dijahit, agar terlihat menarik leaflet didesain secara cermat dilengkapi dengan ilustrasi dan menggunakan bahasa yang sederhana, singkat serta mudah dipahami (Isnian, 2018).

Berbagai media penyuluhan dapat digunakan untuk mengemas informasi dan teknologi yang akan disampaikan kepada petani sebagai pengguna teknologi (Wafi et al., 2015). Penelitian Isnian (2018) mengungkap era revolusi industri 4.0 saat ini, dengan basis data dan jaringan internet sebagai pencirinya, informasi-informasi kepada petani sangat banyak dan mudah diakses, membutuhkan media informasi yang diyakini benar-benar efektif mampu menyampaikan pesan pada sasarannya. Hal ini menjadi tantangan tersendiri bagi medium leaflet untuk dapat meningkatkan keefektifitasannya. Meskipun leafet memiliki keunggulan dibanding media lain dalam jaringan internet, jika tidak dikemas dengan hati-hati, leaflet akan kehilangan fungsinya.

Efektitas adalah alat ukur tercapainya kesuksesan atas tujuan yang ditetapkan (Ratnaningsih \& Suaryana, 2014). Efektifitas diartikan sebagai kemampuan suatu unit yang mencapai tujuan yang diinginkan (Maulana \& Rachman, 2011). Kelurahan Rahandouna Kecamatan Poasia Kota Kendari, dalam upaya meningkatkan pengetahuan petani tentang penyakit bulaipada tanaman jagung, menggunakan medium leafleat. Penyakit bulai adalah penyakit utama pada tanaman jagung yang disebabkan oleh jenis cendawan perenosclerospora sp. yang menyebabkan tanaman terhambat pertumbuhannya (Talanca, 2013). Jagung menjadikomoditas strategis dalampembangunan pertanian dan perekonomian Indonesia, mengingat komoditas ini mempunyai fungsi yang multiguna, baik untuk pangan maupun pakan ternak (Nani \& Sodik, 2006) dan (Surbakti et al., 2013). Kondisi petani yang sejak 3 tahun terakhir memanfaatkan leaflet untuk meningkatkan pengetahuan petani akan penyakit bulai pada usahataninya yakni jagung, sampai saat ini masih ditemukan, sehingga penelitian ini bertujuan untuk mengetahui keefektifitasan leaflet dalam peningkatan pengetahuan petani tentang penyakit bulai pada tanaman jagung di Kelurahan Rahandouna Kecamatan Poasia Kota Kendari, dan berupaya meningkatkan keefektifitasannya melalui desainnya dengan memfokuskan pada desain hurufnya. Diharapkan dari penelitian ini dapat mengungkap keefektifitasan leaflet dan leaflet yang dihasilkan dapat efekti meningkatan pengetahuan petani.

\section{MATERI DAN METODE}

Penelitian ini dilaksanakan pada bulan Januari 2020, yang bertempat di Kelurahan Rahandouna Kecamatan Poasia Kota Kendari. Lokasi penelitian dipilih secara purposive dengan pertimbangan: petani dalam melakukan usahataninya memanfaatkan leaflet untuk meningkatkan pengetahuannya; medium leaflet sebagai alat bantu penyuluhan gunapeningkatkan pengetahuan petani dalam mengendalikan penyakit bulai sudah 3 tahun dilakukan namun belum berhasil; dan Petani dapat membaca dan menulis. Populasi penelitian ini adalah seluruh petani jagung di Kelurahan Rahandouna yang berjumlah 36 orang., yang seluruhnya menjadi responden. Ketigapuluh enam orang dibagi kedalam 3 kelompok yang masing-masing kelompok berjumlah 12 orang.Penelitian didesain sebagai sebagai penelitian "eksperimental" dengan model "One Group Pretest-Posttest design, dengan rangkaian waktu. leaflet diungkap melalui memasukkan leaflet dalam perlakuan desain leaflet dengan fokus pada bentuk hurufnya. Peningkatan desain bentuk huruf dilakukan melalui peubah bebas yang akan diuji kefektifitasnya yakni: Bentuk Huruf Tegak; Bentuk Huruf Miring; dan Huruf Kombinsi Tegak Miring. Huruf yang digunakan adalah dengan model huruf Times New Roman, dengan pertimbangan karena huruf Times new roman adalah model huruf yang digunakan pada medium leafleat yang dimanfaatkan petani selama ini.Data yang diperoleh diolah 
secara kuantitatif dengan menggunakan rumus efektifitas dengan uji $t$ selanjutnya dideskrisikan secara kualitatif.

\section{HASIL DAN PEMBAHASAN}

\section{Karakteristik Responden}

Karakteristik responden adalah suatu kondisi yang menggambarkan keadaan responden yakni petani jagung di Kelurahan Rahandouna. Karakteristik responden yang dimaksud terdiri dari umur, pendidikan, pengalaman berusahatani dan luas lahan garapan yang akan mempengaruhi penerapan teknologi dalam mengelola usahataninya. Karakteristik responden secara detail dapat dilihat pada Tabel 1.

Tabel 1. Karakteristik responden di Kelurahan Rahandouna Kecamatan Poasia Kota Kendari

\begin{tabular}{lccc}
\hline \multicolumn{1}{c}{ Karakteristik Petani } & Kategori & $\begin{array}{c}\text { Jumlah } \\
\text { (Orang) }\end{array}$ & $\begin{array}{c}\text { Persentase } \\
(\%)\end{array}$ \\
\hline Umur & Muda (<45 Tahun) & 13 & 36,11 \\
& Sedang (45-55 Tahun) & 13 & 36,11 \\
Pendidikan Formal & Tua (>55 Tahun) & 10 & 27,78 \\
& SD & 12 & 33,33 \\
Lama BerusahataniJagung & SMP & 9 & 25,00 \\
& SMA & 15 & 41,67 \\
& Kurang (<5 Tahun) & 2 & 5,56 \\
Luas Lahan & Cukup (5-10 Tahun) & 21 & 58,33 \\
& Berpengalaman (>10 Tahun) & 13 & 36,11 \\
Pengalaman dalam Media Cetak & Sempit (<0,5 Ha) & 4 & 11,11 \\
& Sedang (0,5-2,0 Ha) & 31 & 86,11 \\
Pengalaman Huruf & Luas (>2,0 Ha) & 1 & 2,78 \\
& Sedikit (<5 Tahun) & 0 & 0 \\
& Sedang (5-10 Tahun) & 0 & 0 \\
\hline
\end{tabular}

Sumber : Data Primer, 2020

Tabel 1. menunjukkan sebagian besar umur responden terkategori umur produktif, yakni kisaran 15-56 Tahun (BPS, 2015) yang berarti bahwa responden memiliki kemampuan fisik yang masih optimal, indra penglihatan dan ingatan yang sangat baik. Hal ini menjadikan penerapan medium leaflet sebagai alat bantu dalam penyuluhan efektif untuk diterapkan.

Pendidikan formal responden sebagian besar SMA yang menunjukkan bahwa pemanfaatan medium leafleat dapat efektif diterapkan. Meskipun ada responden yang pendidikannya hanya SD, namun itu menunjukkan $100 \%$ responden dapat membaca atau bebas dari buta aksara. Hal ini menegaskan bahwa pemanfaatan medium leaflet di Kelurahan Rahandouna Kecamatan Poasia Kota Kendari bukan sebuah masalah, karena 100\% responden dapat mengambil keuntungan leaflet yakni mampu membaca leaflet secara berulang-ulang. Hasil penelitian ini sesuai pendapat Notoatmodjo (2010) bahwa salah satu faktor leaflet efektif meningkatkan pengetahuan adalah dengan seringnya dibaca.

Lamanya berusahatani jagung kategori cukup dan berpengalaman. Hal ini akan merangsang minat petani untuk meningkatkan pengetahuannya. Hal ini sebagaimana pendapat Yuwono (2001) bahwa salah satu faktor yang mempengaruhi minat petani terhadap usaha taninya adalah luas lahan yang diusahakan, umur, pendidikan, pengalaman. Semakin banyak pengalaman, minat petani dalam berusaha semakin tinggi, dan semakin banyak cara yang mereka lakukan untuk meningkatkan produksi usaha taninya (Erliadi, 2015), dalam hal ini penelitian ini adalah minat terhadap leaflet sebagai upaya petani mencari cara untuk meningkatkan produksi jagungnya.

Tabel 1 menunjukkan sebagian besar responden memiliki luas lahan yang sedang, yang artinya bahwa kebutuhan akan suatu media cetak yang efektif kategori tinggi. Pada lahan sedang memungkinkan kebutuhan akan media penyuluhan yang diyakini efektif dapat meningkatkan pengetahuan petani cenderung tinggi, karena petani bukan berharap pada luas lahan untuk pencapaian produksi namun pada kualitas berusahataninya. Sehingga dibutuhkan medium leaflet yang benar-benar diyakini mampu menyelesaikan masalah petani. Soekartawi (1994) mengatakan bahwa salah satu upaya untuk mengoptimalisasi lahan adalah melalui aspek teknis dengan indicator 
penggunaan sarana produksi dan teknologi sesuai anjuran. Dalam hal penelitian ini teknologi atau pengetahuan yang dapat mengendalikan penyakit Bulai yang salah satu cara memperolehnya melalui medium leaflet.

Pengalaman media cetak reponden $100 \%$ yang artinya semua responden telah akrab dengan media cetak dan bukan lagi hal yang baru. Hal ini membutuhkan desain leafleat hati-hati dan yang inovatif untuk dapat menarik minat petani membaca leaflet. Leaflet yang tidak inovatif akan dianggap biasa saja dengan media cetak lainnya seperti koran, tabloid, bulletin, yang hal ini dapat menurunkan fungsi kerja leaflet dalam meningkatkan pengetahuan petani. Lucie (2005) mengungkapkan bahwa perlu kehati-hatian dalam mendesain leaflet karena meskipun leaflet memiliki banyak kelebihan dibanding media cetak lainnya namun leaflet memiliki kekurangan yakni visual yang terbatas dan hanya melibatkan satu panca indra, yakni penglihatan saja dan butuh proses penggadaan atau desan yang baik, sehingga leaflet yang menarik dan inovatif menjadi niscaya dalam mendesain.

Bentuk huruf tegak dan miring adalah bentuk huruf yang tidak asing bagi petani, meskipun dalam kehidupan sehari-hari berkenaan pemanfaatan media cetak, $100 \%$ petani dengan bentuk huruf tegak. Memasukkan bentuk huruf miring dalam leaflet dapat menjadi sebuah inovasi tersendiri mengingat pengalaman yang digunakan sehari-hari selalu dengan bentuk huruf tegak. Hal ini sebagaimana pendapat Sumiyarso (1992) bahwa untuk mencapai pengembangan pesan dalam komunikasi agar lebih efektif adalah salah satunya membuat sesuatu yang berkesan, dengan memasukkan varisasi huruf yang tidak biasanya.

\section{Efektivitas Medium Leaflet Dalam Meningkatkan Pengetahuan Tentang Penyakit Bulai}

Memastikan efektifitas medium leaflet dalam meningkatkan pengetahuan petani tentang penyakit bulai di Kelurahan Rahandouna Kecamatan Poasia Kota Kendari dilakukan dengan membagi leaflet kedalam 3 perlakuan bentuk huruf, yakni Bentuk Huruf Tegak, Bentuk Huruf Miring, dan Kombinasi Bentuk Huruf Tegak Miring, dengan membandingkan nilai pre test dan post test. Hasil penelitian ditunjukkan pada Tabel 2.

Tabel 2. Efektivitas medium leaflet dalam meningkatkan pengetahuan tentang penyakit bulai di Kelurahan Rahandouna Kecamatan Poasia Kota Kendari

\begin{tabular}{|c|c|c|}
\hline \multirow{2}{*}{ Kelompok Perlakuan } & \multicolumn{2}{|c|}{ Nilai } \\
\hline & Pre-test & Post-test \\
\hline Bentuk Huruf Tegak & 59 & 138 \\
\hline Bentuk Huruf Miring & 92 & 128 \\
\hline Bentuk Huruf Tegak-Miring & 92 & 128 \\
\hline
\end{tabular}

Sumber : Data Primer, 2020

Tabel 2. menunjukkan bahwa pada kelompok perlakuan bentuk huruf tegak, bentuk huruf miring dan bentuk huruf tegak-miring jumlah nilai yang diperoleh pada pre-test dan post-test meningkat. Pada kelompok perlakuan medium leaflet bentuk tegak, nilai pre-test yang diperoleh adalah 59 point sedangkan pada post-test berjumlah 138 point. Pada kelompok perlakuan medium leaflet bentuk huruf miring memperoleh nilai pre-test sebesar 92 point sedangkan pada post-test memperoleh nilai sebesar 128 point dan pada kelompok perlakuan medium leaflet bentuk huruf tegak-miring memperoleh nilai pre-test sebesar 83 point sedangkan pada post-test memperoleh nilai sebesar 141 point. Untuk lebih jelasnya, grafik pada Gambar 1 menunjukkan hal ini.

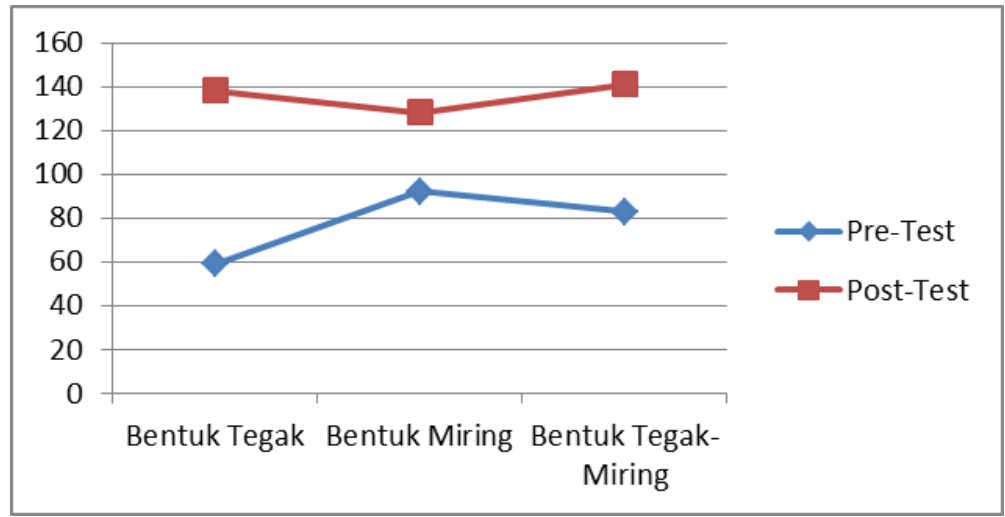

Gambar 1. Peningkatan pengetahuan petani pada medium leaflet tentang penyakit bulan di Kelurahan Rahandouna 
Gambar 1. menunjukkan bahwa terdapat grafik naik setelah perlakuan leaflet pada petani jagung di Kelurahan Rahandouna Kecamatan Poasia Kota Kendari. Grafik naik adalah suatu keadaan yang menunjukkan terjadinya peningkatan pengetahuan dari sebelum dilakukan perlakuan. sebagaimana (KBBI, 2020) menjelaskan peningkatan berate kemajuan, penambahan keterampilan dan kemampuan, yang dalam hal ini pengetahuan petani.

\section{Desain Bentuk Huruf Medium Leaflet Dalam Peningkatan Pengetahuan Petani}

Meningkatkan desain bentuk huruf medium leaflet di Kelurahan Rahandouna Kecamatan Poasia Kota Kendari, dilakukan dengan 3 bentuk perlakuan, yakni perlakuan dengan: Bentuk Huruf Tegak, Bentuk Huruf Miring, dan Kombinasi Bentuk Huruf Tegak Miring. Hasil yang diperoleh ditunjukkan pada Tabel 3.

Tabel 3. Desain bentuk huruf medium leaflet dalam meningkatkan pengetahuan di Kelurahan Rahandouna Kecamatan Poasia Kota Kendari

\begin{tabular}{ccc}
\hline Perlakuan & $\begin{array}{c}\text { Efektifitas } \\
(\%)\end{array}$ & Keterangan \\
\hline Bentuk Huruf Tegak & 65,29 & Efektif \\
Bentuk Huruf Miring & 40,91 & Tidak Efektif \\
Bentuk Huruf Tegak-Miring & 47,25 & Tidak Efektif \\
\hline
\end{tabular}

Sumber : Data Primer, 2020

Tabel 3. menunjukkan bahwa desain bentuk huruf yang efektif dalam meningkatkan pengetahuan petani tentang penyakit bulai di Kelurahan Rahandouna Kecamatan Poasia Kota Kendari adalah desain Bentuk Huruf Tegak, dengan nilai keefektivitasanadalah 65,29\%, sedangkan medium leaflet dengan Bentuk Huruf Miring dan kombinasi Bentuk Huruf Tegak Miring tidak efektif meningkatkan pengetahuan petani di Kelurahan Rahandouna Kecamatan Poasia Kota Kendari, dengan nilai yang diperoleh dibawah $50 \%$. Oleh (Arikunto, 2010), menetapkan kriteria efektifif adalah apabilai nilai yang diperoleh diatas $50 \%$, dan tidak efektif dibawah $50 \%$. Keefektitasan bentuk huruf tegak pada medium leaflet di Kelurahan Rahandouna Kecamatan Poasia Kota Kendari disebabkan oleh pengalaman petani sehari-hari dalam menggunakan ukuran bentuk huruf tegak, dan wujud pesan medium leaflet.

Medium leaflet dengan bentuk huruf tegak sangat sering digunakan dalam keseharian responden sehingga responden merasa nyaman dan mudah dalam membaca dan memahami pesan pada medium leaflet yang diberikan (Hasil wawancara, 2020). Hal ini membuktikan bahwa, penggunaan medium leaflet menjadi hal yang biasa bagi petani khususnya dalam melakukan kegiatan penyuluhan. Kebiasaan responden dalam menggunakan medium leaflet bentuk huruf tegak secara berulang-ulang untuk mencari informasi terkait usahataninya membuat responden terlatih untuk memahami pesan dalam medium leaflet yang digunakan. Hal ini sejalan dengan pernyataan Isnian (2018) yang menyatakan bahwa latar belakang pengalaman dan budaya menentukan kesamaan responden dalam memahami medium leaflet.

Dalam membaca medium leaflet, responden yang terbiasa menggunakan medium leaflet dengan bentuk huruf tegak, tentunya akan lebih cepat menerima informasi karena terbiasa membaca medium leaflet dengan desain model tersebut. Rahmat (2000) menyatakan bahwa bentuk dan ukuran medium leaflet dengan ukuran yang telah ditentukan dan diterima responden memberikan stimulus lewat indera menuju ke otak. Kebiasaan responden membuat indera mereka terlatih sehingga hal tersebut memudahkan bagi responden dalam memahami pesan pada medium leaflet bentuk huruf tegak. Selain itu, legability dan keterbacaan medium leaflet dengan bentuk huruf tegak lebih baik karena bentuk tegak sering dilihat dan digunakan dalam kehidupan sehari-hari. Legability adalah tingkat kemudahan mata dalam mengenali suatu tulisan tanpa harus bersusah payah seperti kerumitan desain huruf, penggunaan warna, dan frekuensi menemui huruf tersebut dalam kehidupan sehari-hari, sedangkan keterbacaan adalah tingkat kenyamanan suatu huruf saat dibaca seperti jenis dan ukuran huruf.

Berbeda dengan medium leaflet dengan bentuk huruf tegak, medium leaflet dengan bentuk huruf miring memiliki legability dan keterbacaan yang tidak begitu baik karena bentuk hurufnya yang dimiringkan mempengaruhi kemudahan dan kenyamanan responden dalam membaca medium leaflet. Penggunaan huruf miring secara keseluruhan pada medium leaflet yang tidak pernah didapatkan atau dilihat responden dalam kehidupan sehari-hari membuat responden kesulitan membaca dan memahami informasi yang ada pada medium leaflet dengan bentuk huruf miring sehingga mempengaruhi keefektivitasan medium leaflet tersebut. Huruf yang tercetak miring biasanya digunakan untuk memberikan penekanan pada sebuah kata dan untuk menonjolkan 
sesuatu yang penting atau istilah tertentu. Rahmaningsih (2016) dan Arisman (2015) menyatakan bahwa huruf miring digunakan untuk memberikan penekanan pada sebuah kata, untuk menulis majalah, surat kabar yang dikutip dalam tulisan, untuk menulis nama ilmiah, menunjukkan istilah atau bahasa asing dan digunakan sebagai headline atau sub-head serta highlight dari naskah.

Seperti halnya medium leaflet dengan bentuk huruf miring, medium leaflet menggunakan bentuk huruf tegak-miring juga memiliki legability dan keterbacaan yang tidak begitu baik karena menggunakan bentuk huruf gabungan dari bentuk huruf tegak dan bentuk huruf miring yang berdampak pada penglihatan responden ketika membaca medium leaflet dengan bentuk huruf tegakmiring menjadi kesulitan untuk memahami informasi yang ada pada medium leaflet tersebut. Kamil et al. (2013) yang menunjukkan bahwa huruf dan warna yang terdapat pada media cetak merupakan salah satu komponen yang paling penting karena mempengaruhi kenyamanan membaca media cetak.Selain itu, bentuk huruf tegak-miring tidak pernah digunakan atau dilihat oleh responden dalam kehidupan sehari-hari yang membuat responden menjadi tidak nyaman dalam membaca medium leaflet tersebut sehingga berdampak pada ketidakefektifan medium leaflet menggunakan ukuran huruf times new roman font 12 dengan bentuk huruf tegak-miring.

\section{KESIMPULAN DAN SARAN}

Berdasarkan hasil penelitian dan pembahasan, maka dapat disimpulkan bahwa medium leafleat efektif diterapkan untuk meningkatkan pengetahuan petani di Kecamatan Poasia Kota Kendari, dengan desain bentuk huruf tegak. Keefektifitasan desain bentuk huruf tegak disebabkan karena sasaran meliputi pengalaman dan budaya, dan wujud pesan meliputi legability dan tingkat keterbacaan yang sangat baik.Disarankan kepada pemerintah dan pihak-pihak terkait dalam melakukan penyuluhan pertanian berkenaan dengan pengetahuan hendaknya tetap mempertahankan penggunaan leaflet, dan menerapkan desain bentuk huruf tegak pada medium leaflet.Pada peneliti diharapkan dapat mengembangkan penelitian-penelitian serupa dengan memfokuskan pada pengembangan inovatif desain medium leaflet.

\section{REFERENSI}

Arikunto, S. (2010). Prosedur Penelitian Suatu Pendekatan Praktik. PT. Rineka Cipta.

Arisman, A. (2015). Efektivitas Penggunaan Media Cetak Terhadap Peningkatan Pengetahuan Petani Dalam Pembuatan Pupuk Bokashi Di Desa Wonua Kecamatan Konda Kabupaten Konawe Selatan Halu Oleo]. Kendari.

Ban, A. V. D., \& Hawkins, H. S. (1999). Penyuluhan Pertanian. Kanisius.

Bovee, C. L., \& Arens, W. F. (1986). Cortemporary Advertising, Homewood, Illinois: Richard D. Irwin.

BPS. (2015). Kota Kendari Dalam Angka. Badan Pusat Statistik.

Erliadi. (2015). Faktor-Faktor yang Mempengaruhi Minat Petani Menggunakan Benih Varietas Unggul pada Usahatani Padi sawah (Pryza sativa, L) di Kecamatan Manyak Payed Kabupaten Aceh Tamiang. Jurnal Agrisamudra, 2(1), 91-100.

Gani, H. A., Istiaji, E., \& Kusuma, A. I. (2014). Perbedaan Efektivitas Leaflet dan Poster Produk Komisi Penanggulangan AIDS Kabupaten Jember Dalam Perilaku Pencegahan HIV/AIDS. Jurnal IKESMA, 10(1), 31-48.

Isnian, S. N. (2018). Desain Huruf Media Cetak Leaflet Pada Peningkatan Pengetahuan Ibu-lbu Tentang Bertanam Jahe Di Kota Kendari. Buletin Penelitian Sosek, 20(1), 14-26.

Kamil, S., Ibnu, I. F., \& Rachman, W. A. (2013). Media Cetak Komunikasi Informasi Edukasi (KIE) Dalam Pengobatan Pasien Tubercolosis Type Multy Drug Resistant (TB-MDR) Di Kota Makassar. Artikel Online.

KBBI. (2020). http://bahasa.kemdiknas.go.id/kbbi/index.php. Diakses pada tanggal 28 September 2020.

Kementan. (2018). Peraturan Menteri Pertanian Republik Indonesia Nomor: 03/Permentan/SM.200/1/2018 Tentang Pedoman Penyelenggaraan Penyuluhan Pertanian.

Lucie. (2005). Teknik Penyuluhan dan Pemberdayaan Masyarakat. Galia Indonesia.

Manyamsari, I., \& Mujibburrahmad. (2014). Karakteristik Petani dan Hubungannya Dengan Kompetensi Petani lahan Sempit (Kasus: Di Desa Sinar Sari Kecamatan Dramaga Kabupaten Bogor Jawa Barat). Jurnal Agrisep, 15(2), 58-74.

Mardikanto, T. (2010). Sistem Penyuluhan Pertanian. Sebelas Maret University Press.

Maulana, M., \& Rachman, B. (2011). Harga Pembelian Pemerintah (HPP) Gabah-Beras Tahun 2010: Efektivitas dan Implikasinya Terhadap Kualitas dan Pengadaan oleh Dolog. Analisis Kebijakan Pertanian, 9(4), 331-347. 
Nani, D. R., \& Sodik, M. (2006). Pemberian Bokashi Tanah Berpasir Terhadap Pertumbuhan Tanaman Jagung. Jurnal Penelitian dan Kajian IImu Pertanian, 2, 6-11.

Nazariah. (2012). Pengembangan Informasi Melalui Media Cetak Elektronik/Cetak. Balai Pengkajian Teknologi Pertanian.

Notoatmodjo, S. (2010). IImu Kesehatan Masyarakat. PT. Rhineka Cipta.

Palan, R. (2008). Competency Management Teknik Mengimplementasikan Managemen SDM Berbasis Kompetensi Untuk Meningkatkan Daya saing Organisasi. PPM. Anggota IKAPI. Peraturan Pemerintah (PP).

Rahmaningsih, P. (2016). Mengajarkan Ejaan Pada Siswa Sekolah Dasar. Jurnal IImiah Guru "COPE", No. 01 Tahun XX.

Rahmat, J. (2000). Psikologi Manusia. Rema Rosda Karya.

Ratnaningsih, K. I., \& Suaryana, I. G. N. A. (2014). Pengaruh Kecanggihan Teknologi Informasi, Partisipasi Manajemen dan Pengetahuan Manajer Akuntansi Pada Efektivitas Sistem Informasi Akutansi. E-Jurnal Akuntansi Universitas Udayana, 6(1), 1-16.

Ruyadi, I., Winoto, Y., \& Komariah, N. (2017). Media Komunikasi dan Informasi Dalam Menunjang Kegiatan Penyuluhan Pertanian. Jurnal Kajian Informasi dan Perpustakaan, 5(1), 37-50.

Soekartawi. (1994). Teori Ekonomi Produksi dengan Pokok Bahasan Analisis Fungsi Cobb-Douglas. PT. Raja Grafindo

Sumiyarso. (1992). Pengaruh Warna Foto dan Jumlah Kolom Dalam Selebaran Tentang Campak Pada Peningkatan Pengetahuan Para Ibu-lbu di Desa Jonggol Kecamatan Jonggol Kabupaten Bogor Institut Pertanian Bogor]. Bogor.

Surbakti, M. F., Ginting, S., \& Ginting, J. (2013). Pertumbuhan dan Produksi Jagung (Zea mays L.) Varietas Pioneer-12 dengan Pemangkasan Daun dan Pemberian Pupuk NPKMg. Jurnal Online Agroekoteknologi, 1(3), 523-534.

Talanca, A. H. (2013). Status Penyakit Bulai Tanaman Jagung dan Pengendalinya. Seminar Nasional Inovasi Teknologi Pertanian.

Wafi, A., A, S., Risanti, C. N., Adawiyah, K. A., H, S., \& E, J. (2015). Media Penyuluhan Universitas Jambi]. Jambi.

Yuwono. (2001). Pengertian Minat dan Keinginan. http://yuwono.co.id Di Akses Pada Tanggal 28 September 2020. 